\title{
KLAUSULA EKSONERASI DALAM DOKUMEN ANGKUTAN UDARA PADA PERUSAHAAN PENERBANGAN LION AIR
}

\author{
Angger Puja Andhika Adityawarman \\ Program Studi Magister Ilmu Hukum \\ Pascasarjana Universitas Islam Bandung \\ Email : andhikaangger@gmail.com
}

\begin{abstract}
Abstrak - Klausula eksonerasi merupakan suatu klausul yang membatasi atau menghindari tanggung jawab pelaku usaha kepada konsumen. Klausula eksonerasi umumnya sangat memberatkan atau bahkan cenderung merugikan konsumen karena menimbulkan adanya ketidakseimbangan kedudukan dalam suatu perjanjian. Penulisan ini bertujuan untuk mengetahui dan memahami klausula eksonerasi dalam dokumen angkutan udara pada perusahaan penerbangan Lion Air dihubungkan dengan UndangUndang Nomor 8 Tahun 1999 tentang Perlindungan Konsumen juncto peraturan perundang-undangan di bidang angkutan udara dan asas keseimbangan. Penelitian ini menggunakan metode pendekatan yurudis normatif. Data yang digunakan ialah data sekunder yang terdiri dari bahan-bahan hukum primer, bahan hukum sekunder, dan bahan hukum tersier. Teknik pengumpulan data yang digunakan adalah studi kepustakaan. Data yang diperoleh dianalisis menggunakan metode yuridis kualitatif. Hasil penelitian menunjukan bahwa klausula eksonerasi dalam dokumen angkutan udara perusahaan penerbangan Lion Air bertentangan dengan undang-undang dan asas keseimbangan karena merupakan klausula yang menyatakan pengalihan tanggung jawab atas keterlambatan pengangkutan yang dilarang dicantumkan dalam suatu perjanjian.
\end{abstract}

\section{Kata Kunci : Klausula Eksonerasi, Asas Keseimbangan, Perjanjian}

\begin{abstract}
Exoneration clause is a clause that limits or avoids the responsibility of business actors to consumers. It is generally very burdensome or even tends to harm consumers because it causes an imbalance of position in an agreement. This study aimed at finding out and understanding the exoneration clause in the air transportation document at the Lion Air airline associated with Law Number 8 Year 1999 concerning Consumer Protection juncto the laws and regulations in the field of air transportation and the principle of balance. This study used normative juridical approach. It also used secondary data consisting of primary legal materials, secondary legal materials, and tertiary legal materials. The data collection technique used literature study. Then, those data were analyzed using qualitative juridical method. The result shows that the exoneration clause in the air transportation document at the Lion Air airline was contrary to the law and the principle of balance because it was a clause stating the transfer of responsibility for delays in transportation prohibited from being included in an agreement.
\end{abstract}

Keyword : Exoneration Clause, Balance Principle, Agreement 


\section{A. Pendahuluan}

Kontrak baku, kontrak standar atau kontrak adhesi adalah beberapa istilah yang digunakan terhadap perjanjian yang seluruh klausulklausulnya sudah dibakukan oleh pemakainya dan pihak yang lain pada dasarnya tidak mempunyai peluang untuk merundingkan atau minta perubahan. (Sutan Remy Sjahdeini, 1993 :66) Dalam perjanjian demikian pihak yang ditawarkan perjanjian hanya tinggal menyatakan mau menerima atau menolak (take it or leave it atau dalam istilah Sunda, wantun galeuh teu wantun ulah geuleuh - berani beli tidak berani jangan benci). (Toto Tohir Suriaatmadja, 2006:42)

Latar belakang yang mendasari lahirnya klausula baku adalah efisiensi dan efektivitas dalam berkontrak. (Ahmad Miru, Sutarman Yodo, 2005:112) Perjanjian baku merupakan pembakuan atau standarisasi agar transaksi dapat dilaksanakan secara cepat. Oleh karena itu, syarat-syarat yang telah disepakati itu dibakukan, artinya ditetapkan sebagai tolak ukur bagi setiap pihak yang membuat perjanjian dengan pengusaha yang bersangkutan. (Soejono

Dirdjosisworo, 2006:51) Dengan penggunaan perjanjian yang memuat klausula baku ini, maka pengusaha akan memperoleh efisiensi dalam pengeluaran biaya, tenaga, dan waktu. (Mariam Darus Badrulzaman, 1994:46)

Dalam dunia bisnis, penggunaan perjanjian atau kontrak baku tersebut salah satunya terdapat dalam bidang usaha pengangkutan udara. Pada prinsipnya terlaksananya pengangkutan melalui udara karena adanya perjanjian antara pengangkut dan penumpang. Sifat perjanjian pengangkutan adalah timbal balik, baik antara pengangkut dengan penumpang atau pengirim barang (pengguna jasa) masing-masing mempunyai hak dan kewajibannya. Kewajiban pengangkut adalah menyelenggarakan pengangkutan dari suatu tempat ke tempat tujuan tertentu dengan selamat, dan berhak atas biaya angkutan. Sedangkan kewajiban penumpang dan/atau pengirim barang ialah membayar ongkos angkut dan berhak untuk diangkut ke tempat tujuan tertentu 
dengan selamat sesuai yang diperjanjikan. (Siti Nurbaiti, 2007:10) Dengan demikian, kedudukan para pihak dalam perjanjian pengangkutan pada prinsipnya adalah sama tinggi atau koordinasi (gecoordineerd). (H.M.N. Purwosutjipto, 1991:7)

Perjanjian pengangkutan yang telah disepakati tersebut dibuktikan dengan adanya dokumen angkutan, salah satunya yaitu tiket penumpang angkutan udara pada perusahaan penerbangan Lion Air. Pada tiket penumpang pesawat udara tercantum apa yang disebut syarat-syarat dan ketentuan-ketentuan perjanjian (conditions of contract), dimana mengenai klausula-klausula di dalamnya telah dibakukan secara sepihak oleh pihak pengangkut dan berlaku umum (massal). Hal tersebut berarti tiket penumpang pesawat udara merupakan suatu bentuk kontrak baku yang tidak ditandatangani oleh kedua belah pihak yang merupakan bagian dari perjanjian pengangkutan, tetapi mengikat kedua belah pihak, baik pihak pengangkut maupun pihak penumpang yang membeli tiket tersebut. (Munir Fuady, 2008:92)

$$
\text { Pasal } 18 \text { Undang-Undang }
$$
Nomor 8 Tahun 1999 tentang Perlindungan Konsumen (selanjutnya disebut UUPK) sebenarnya tidak melarang dibuatnya perjanjian dengan mencantumkan klausula baku di dalam perjanjian yang dibuat pelaku usaha, atau dengan kata lain pencantuman klausula baku dalam perjanjian sah-sah saja dibuat, akan tetapi substansinya tidak boleh mengalihkan tanggung jawab dari pihak pelaku usaha kepada konsumen. Dalam kalimat lain, klausula baku tidak boleh membatasi atau menghindari tanggung jawab pelaku usaha kepada konsumen atau yang disebut dengan klausula eksonerasi.

Klausula eksonerasi ini umumnya sangat memberatkan atau bahkan cenderung merugikan konsumen, sehingga menimbulkan adanya kondisi ketidakseimbangan pengaturan hak dan kewajiban antara pelaku usaha dan konsumen dalam kontrak. Ketidakseimbangan tersebut umumnya akan merugikan konsumen selaku pihak yang disodorkan 
perjanjian yang memuat klausula baku di dalamnya. Tujuan adanya larangan tersebut dalam UUPK adalah untuk menempatkan kedudukan konsumen setara dengan pelaku usaha. (Heru P. Sanusi, at. al., 2006:69)

Tetapi pada kenyataan yang terjadi, walaupun Pasal 18 UUPK telah mengatur larangan pencantuman klausula eksonerasi dalam suatu dokumen atau perjanjian yang dibuat pelaku usaha, ternyata tidak menyurutkan keinginan pelaku usaha untuk melakukannya, seperti halnya klausula eksonerasi yang tercantum dalam dokumen angkutan udara perusahaan penerbangan Lion Air yang menyatakan tidak bertanggung jawab atas kerugian apapun juga yang ditimbulkan oleh pembatalan dan/atau keterlambatan pengangkutan ini, termasuk segala keterlambatan datang penumpang dan/atau keterlambatan penyerahan bagasi.

\section{Identifikasi Masalah}

Pertama, bagaimana klausula eksonerasi dalam dokumen angkutan udara pada perusahaan penerbangan Lion Air dihubungkan dengan UUPK juncto peraturan perundangundangan di bidang angkutan udara ? Kedua, bagaimana dokumen angkutan udara pada perusahaan penerbangan Lion Air yang mengandung klausula eksonerasi ditinjau berdasarkan asas keseimbangan.

\section{Tujuan Penelitian}

Pertama, untuk mengetahui klausula eksonerasi dalam dokumen angkutan udara pada perusahaan penerbangan Lion Air dihubungkan dengan UUPK juncto peraturan perundang-undangan di bidang angkutan udara. Kedua, untuk memahami dokumen angkutan udara pada perusahaan penerbangan Lion Air yang mengandung klausula eksonerasi ditinjau berdasarkan asas keseimbangan.

\section{B. Metode Penelitian}

Penelitian ini merupakan suatu penelitian yuridis normatif yang bersifat deskriptif analisis, karena penelitian ini berbasis pada analisis norma hukum. Oleh karena penelitian ini merupakan penelitian yuridis normatif, maka sumber datanya adalah berupa data sekunder 
berupa bahan-bahan hukum, yang dilakukan melalui studi dokumen terhadap data sekunder yang diperoleh dengan menggunakan metode penelitian kepustakaan. Keseluruhan data sekunder yang diperoleh diolah dan dianalisis dengan menggunakan pendekatan kualitatif dengan menghubungkan ketentuan-ketentuan hukum perlindungan konsumen tentang klausula baku pada dokumen angkutan udara dan asas keseimbangan dalam perjanjian pengangkutan.

\section{Hasil dan Pembahasan}

1) Klausula

Eksonerasi

Berdasarkan UUPK juncto

Peraturan

Perundang-

Undangan

di

Bidang Angkutan Udara

Dari sisi perlindungan konsumen, penggunaan klausula baku dalam perjanjian diatur dalam UUPK sebagai wujud perlindungan hukum terhadap konsumen atas perjanjian yang dibuat oleh pelaku usaha. (Sri Redjeki Hartono, Husni Syawali, Neni Sri Imaniyati, 2000:78) Pasal 18 UUPK mengatur bahwa dalam menawarkan barang dan/atau jasa yang ditujukan untuk diperdagangkan, pelaku usaha dilarang membuat atau mencantumkan klausula baku pada setiap dokumen dan/atau perjanjian, apabila klausula baku tersebut isinya menyatakan pengalihan tanggung jawab pelaku usaha.

Pelaku usaha yang mencantumkan klausula baku yang menyatakan pengalihan tanggung jawab pelaku usaha sebagaimana dimaksud dalam Pasal 18 UUPK dalam dokumen dan/atau perjanjian yang dibuatnya, dapat dikenakan sanksi perdata, yakni perjanjian baku atau klausula baku yang dibuatnya jika digugat oleh konsumen akan berakibat batal demi hukum (void) sebagaimana diatur dalam Pasal 18 ayat (3) UUPK, serta pelaku usaha yang bersangkutan wajib merevisi perjanjian baku yang digunakannya itu sesuai dengan ketentuan Pasal 18 UUPK. Disamping sanksi perdata, pelaku usaha yang bersangkutan juga dapat dikenakan sanksi pidana, yakni penjara paling lama 5 (lima) tahun atau pidana denda paling banyak Rp.2,000,000,000,- (dua miliar 
rupiah), sebagaimana yang ditetapkan dalam ketentuan Pasal 62 ayat (1) UUPK.

Selain itu, berkaitan dengan klausula eksonerasi dalam dokumen angkutan udara. Sebagai bukti adanya perjanjian pengangkutan antara pengangkut dan penumpang yang juga merupakan hubungan hukum yang terjadi antara pelaku usaha jasa angkutan udara dan konsumen, perlu dikaji pula mengenai pengaturan yang terdapat dalam undang-undang di bidang angkutan udara khususnya mengenai tanggung jawab atas keterlambatan dalam pengangkutan udara sebagaimana dimaksud dalam Pasal 64 UUPK yang menjadi dasar berlakunya peraturan perundangundangan lainnya diluar UUPK yaitu Undang-Undang Nomor 1 Tahun 2009 tentang Penerbangan (selanjutnya disebut UU Penerbangan) sebagai pengaturan yang khusus mengatur mengenai tangggung pengangkut di bidang angkutan udara (lex spesialis).

Delay adalah keterlambatan atau penundaan penerbangan keberangkatan pesawat terbang berjadwal dari jadwal/schedule yang telah ditetapkan.(Sri Sutarwati, Hardiyana, Novita Karolina, 2016:17) Menurut Eurocontrol, "delay is the time lapse which occurs when a planned event does not happen at the planned time".(European Observatory on Airport Capacity \& Quality, 2015:5)

Menurut Pasal 1 angka 30 UU Penerbangan juncto Pasal 1 angka 13 Peraturan Menteri Perhubungan Nomor 77 Tahun 2011 tentang Tanggung Jawab Pengangkut (selanjutnya disebut Permenhub 77/2011) juncto Pasal 1 angka 6 Peraturan Menteri Perhubungan Nomor 89 Tahun 2015 tentang Penanganan Keterlambatan Penerbangan (Delay Management) Pada Badan Usaha Angkutan Udara Niaga Berjadwal Di Indonesia (selanjutnya disebut Permenhub 89/2015), keterlambatan diartikan sebagai perbedaan waktu keberangkatan atau kedatangan yang dijadwalkan dengan realisasi waktu keberangkatan atau kedatangan. Keterlambatan dapat pula diartikan tidak terpenuhinya jadwal penerbangan yang telah ditetapkan 
oleh perusahaan penerbangan komersial berjadwal karena berbagai faktor. (Mhd. Subhi Solih Hasibuan Tan Kamello, Hasim Purba, Rosnidar Sembiring, 2017:82)

Dalam hal ketiadaan jadwal penerbangan, keterlambatan ditentukan berdasarkan waktu yang layak. Dalam menentukannya dilihat dari sifat, tarif, dan susasana yang ada dalam angkutan udara umumnya yaitu kejadian-kejadian yang akan mempengaruhi pengangkutan udara dari keterlambatan. (Toto Tohir Suriatmadja, 2005:94)

Sehubungan dengan itu, Pasal 146 UU Penerbangan juncto Pasal 2 huruf e Permenhub 77/2011 menyatakan bahwa pengangkut bertanggung jawab terhadap keterlambatan kecuali apabila pengangkut dapat membuktikan bahwa keterlambatan tersebut disebabkan faktor cuaca dan teknis operasional. Pasal 2 Permenhub 89/2015 juncto Pasal 9 Permenhub 77/2011 menyebutkan bahwa keterlambatan penerbangan pada badan usaha angkutan udara niaga berjadwal terdiri dari : a. keterlambatan penerbangan (flight delayed);

b. tidak terangkutnya penumpang dengan alasan kapasitas pesawat udara (denied boarding passenger); dan

c. pembatalan penerbangan (cancelation of flight).

Dalam hal terjadi keterlambatan penerbangan (flight delayed) badan usaha angkutan udara wajib memberikan kompensasi dan ganti rugi kepada penumpangnya. Pasal 3 Permenhub 89/2015, keterlambatan penerbangan dikelompokan menjadi 6 kategori keterlambatan, yaitu :

1. Kategori 1, keterlambatan 30 menit s/d 60 menit;

2. Kategori 2, keterlambatan 61 menit s/d 120 menit;

3. Kategori 3, keterlambatan 121 menit s/d 180 menit;

4. Kategori 4, keterlambatan 181 menit s/d 240 menit;

5. Kategori 5, keterlambatan lebih dari 240 menit; dan

6. Kategori 6, pembatalan penerbangan.

Pasal 9 Permenhub 89/2015, kompensasi yang wajib diberikan 
badan usaha angkutan udara akibat keterlambatan penerbangan itu berupa :

a. keterlambatan kategori 1, kompensasi berupa minuman ringan;

b. keterlambatan kategori 2, kompensasi berupa minuman dan makanan ringan (snack box);

c. keterlambatan kategori 3, kompensasi berupa minuman dan makanan berat (heavy meal);

d. keterlambatan kategori 4, kompensasi berupa minuman, makanan ringan (snack box), dan makanan berat (heavy meal);

e. keterlambatan kategori 5, kompensasi berupa ganti rugi sebesar Rp. 300.000 (tiga ratus ribu rupiah);

f. keterlambatan kategori 6 , badan usaha angkutan udara wajib mengalihkan ke penerbangan berikutnya atau mengembalikan seluruh biaya tiket (refund ticket);

g. keterlambatan pada kategori 2 sampai dengan 5, penumpang dapat dialihkan ke penerbangan berikutnya atau mengembalikan seluruh biaya tiket (refund ticket).

Menurut Pasal 5 Permenhub 89/2015, pada kondisi tertentu, badan usaha angkutan udara dibebaskan dari tanggung jawab atas ganti kerugian akibat keterlambatan penerbangan diantaranya keterlambatan yang disebabkan oleh

a. Faktor teknis operasional, yakni faktor yang disebabkan oleh kondisi bandar udara pada saat keberangkatan atau kedatangan yang meliputi :

1. Bandar udara untuk keberangkatan dan tujuan tidak dapat digunakan oleh operasional pesawat udara;

2. Lingkungan menuju bandar udara atau landasan terganggu fungsinya misalnya retak, banjir, atau kebakaran;

3. Terjadinya antrian pesawat udara lepas landas (take off), mendarat (landing), atau alokasi waktu keberangkatan (departure slot time) di bandar udara; atau

4. Keterlambatan pengisian bahan bakar (refuelling). 
b. Faktor cuaca seperti hujan lebat; banjir; petir; badai;. kabut; asap; jarak pandang di bawah standar minimal; atau kecepatan angin yang melampaui standar maksimal yang mengganggu keselamatan penerbangan.

c. Faktor lain-lain yang disebabkan di luar faktor manajemen airlines, teknis operasional dan cuaca, antara lain kerusuhan dan/atau demonstrasi di wilayah bandar udara.

2) Klausula Eksonerasi Ditinjau

\section{Berdasarkan}

Asas

\section{Keseimbangan}

Asas keseimbangan dalam perjanjian pada hakekatnya menghendaki adanya kondisi yang seimbang (bargaining power) diantara para pihak dalam perjanjian. (Sutan Remi Sjahdeni, 1993:49) Keseimbangan kondisi tersebut dimaknai dengan adanya pemenuhan dan pelaksanaan prestasi yang telah disepakati dalam suatu perjanjian. Dengan demikian, keseimbangan dapat terwujud apabila ada itikad baik masing-masing pihak dalam perjanjian. (Mariam Darus Badrulzaman, 2001:38)

Dalam suatu kontrak baku, itikad baik harus sudah ada tidak hanya pada saat pemenuhan atau pelaksanaan apa yang menjadi prestasi kedua belah pihak. Akan tetapi itikad baik juga harus telah diterapkan pada tahap sebelum kontrak tersebut ditanda-tangani oleh kedua belah pihak. Mengingat dalam kontrak baku mengenai syarat-syarat perjanjian telah ditentukan terlebih dahulu oleh salah satu pihak tanpa bisa di negosiasikan kembali. Untuk itu, itikad baik menjadi indikator utama dalam melihat ada atau tidaknya keseimbangan dalam suatu kontrak baku.

Menurut pendapat Herlien Budiono bahwa untuk menguji ada atau tidak keseimbangan dalam suatu perjanjian dapat diuji berdasarkan 3 (tiga) indikator yaitu dari perbuatan para pihaknya, apa yang menjadi syarat atau isi perjanjian dan pelaksanaan dari apa yang telah menjadi kesepakatan perjanjian. Ketiga indikator penguji ada atau tidaknya keseimbangan dalam suatu perjanjian tersebut erat kaitannya 
dengan asas-asas pokok dalam hukum perjanjian yaitu asas konsensualisme, asas kekuatan mengikat, dan asas kebebasan berkontrak. (Herlien Budiono, 2006:334)

Lebih lanjut, menurut Herlien Budiono asas keseimbangan memegang peranan penting yang bersifat pilihan atau alternatif, dimana asas keseimbangan dapat bersifat pelengkap atau bersifat sebagai asas pokok lainnya dalam hukum perjanjian. Mengenai alternatif pertama, asas keseimbangan diartikan sebagai asas pelengkap dalam arti asas ini akan terwujud apabila asas-asas lainnya dalam hukum kontrak yaitu asas konsensualisme, kekuatan mengikat dan kebebasan berkontrak telah di fungsikan secara baik dalam suatu perjanjian. Sebalinya, pada alternatif kedua, asas keseimbangan diartikan sebagai asas pokok sama halnya dengan ketiga asas lainnya. Asas keseimbangan sebagai asas pokok disini diartikan bahwa meskipun pada praktiknya ketiga asas pokok lainnya telah difungsikan secara baik namun tidak otomatis suatu perjanjian telah memenuhi asas keseimbangan. Dimana tolak ukur keseimbangan tersebut harus memenuhi asas konsensualisme, asas kekuatan mengikat, asas kebebasan berkontrak, dan asas keseimbangan. (Herlien Budiono, 2006:359)

Dikaitkan dengan klausula eksonerasi atas keterlambatan yang tercantum dalam tiket penumpang Lion Air, dengan adanya klausula eksonerasi tersebut tentu sangat merugikan konsumen atau pengguna jasa, dimana pengangkut bebas dari tanggung jawab atas kerugian yang timbul dari adanya keterlambatan pengangkutan udara. Pihak penumpang yang telah memenuhi kewajibannya dengan membayar ongkos angkut akan tetapi hak penumpang atas pemenuhan perjanjian sesuai yang dijanjikan dilanggar tanpa adanya kewajiban pengangkut untuk memberikan kompensasi atas kerugian yang dialami penumpang yang diakibatkan pengangkutan tidak berjalan sebagaimana mestinya.

Merujuk pada pendapat Herlin Budiono untuk mengetahui ada atau tidaknya keseimbangan dalam kasus 
Lion Air tersebut harus diuji berdasarkan 3 (tiga) indikator penguji asas keseimbangan. Pertama, perbuatannya sendiri atau pelaku individual. Mengenai indikator pertama ini erat kaitannya dengan asas konsensualisme dalam perjanjian. Berdasarkan asas konsensual, pada dasarnya perjanjian telah dilahirkan begitu adanya kata sepakat diantara kedua belah pihak, dimana kata sepakat tersebut menjadi cacat jika didalamnya terkandung unsur perbuatan-perbuatan yang mengakibatkan cacatnya kehendak yaitu adanya ancaman, penipuan, dan termasuk didalamnya yaitu penyalahgunaan keadaan. (Herlien Budiono, 2006:335)

Dikaitkan dengan pencantuman klausula eksonerasi atas keterlambatan pengangkut dalam dokumen angkutan udara perusahaan Lion Air, dapat disimpulkan kesepakatan kedua belah pihak dalam hal ini menjadi cacat hukum dikarenakan adanya itikad tidak baik dari pihak Lion Air untuk tidak melakukan pemenuhan dan pelaksanaan prestasi yang sudah diperjanjikan. Karena pada umumnya dalam tiket penumpang telah dicantumkan jadwal atau waktu keberangkatan yang telah ditentukan dan disetujui oleh para pihak akan tetapi Lion Air menghindari tanggung jawabnya untuk melaksanakan apa yang telah ia tentukan sendiri.

Cacatnya persesuaian kehendak para pihak akibat adanya pencantuman klausula eksonerasi tersebut dapat disimpulkan karena adanya penyalahgunaan keadaan yang dilakukan oleh pihak Lion Air. Hal tersebut terjadi karena pada dasarnya Lion Air memiliki keunggulan ekonomis selaku pelaku usaha dibandingkan penumpang selaku konsumen. Keunggulan ekonomis tersebut karena pihak Lion Air adalah selaku pihak yang membuat dan menyodorkan kontrak baku kepada penumpang, dimana atas keunggulan ekonomis tersebut Lion Air telah menyalahgunakan posisinya dengan mencantumkan suatu klausul yang dilarang oleh undang-undang. Ini berarti ada itikad tidak baik pihak Lion Air dalam membuat suatu kontrak baku dengan 
menghapus tanggung jawab yang semestinya dibebankan kepadanya.

Kedua, mengenai isi perjanjian erat kaitannya dengan asas kebebasan berkontrak. Asas kebebasan berkontrak memiliki ruang lingkup berupa kebebasan melakukan perjanjian dengan siapa saja dan mengenai apa saja yang tidak bertentangan dengan hukum, kepatutan, dan kesusilaan. Dalam perjanjian yang memuat klausula baku dikatakan sebagai pembatasan dari asas kebebasan berkontrak dikarenakan dalam perjanjian demikian pihak lainnya tidak diberikan kesempatan untuk dapat menegosiasikan isi perjanjian. Kebebasan berkontrak dalam perjanjian yang memuat klausula baku tersebut tercermin dari sifat take it or leave it, dimana pihak lain tetap diberikan pilihan untuk dapat menyetujui ataupun menolak perjanjian yang disodorkan kepadanya. Adanya klausula eksonerasi dalam dokumen angkutan udara perusahaan penerbangan Lion Air atas keterlambatan tersebut dapat dikatakan telah mencederai asas kebebasan berkontrak dikarenakan isi klausula tersebut secara tegas dianggap melanggar ketentuan dalam UUPK dan UU Penerbangan.

Selain itu, berdasarkan asas kekuatan mengikat (pacta sund servanda), dimana suatu perjanjian adalah mengikat para pihak apabila telah memenuhi syarat sahnya suatu perjanjian. Isi perjanjian atau suatu klausula yang tercantum dalam perjanjian juga erat kaitannya dengan syarat sahnya perjanjian yaitu causa atau sebab yang halal. Inti dari syarat tersebut bahwa suatu isi perjanjian dikatakan halal atau sah secara hukum apabila tidak dilarang oleh undang-undang.

Isi klausula eksonerasi yang mengatur mengenai keterlambatan dalam dokumen angkutan Lion Air merupakan klausula yang dilarang dicantumkan dalam suatu perjanjian yang memuat klausula baku didalamnya. Adanya klausula tersebut ditafsirkan bahwa Lion Air selaku pihak pengangkut telah menghilangkan tanggung jawabnya atas kerugian yang terjadi atas keterlambatan apapun, dimana hal tersebut telah bertentangan dengan UUPK dan undang-undang di bidang 
angkutan udara yang mengatur bahwa pengangkut bertanggung jawab atas keterlambatan pengangkutan sampai pengangkut dapat membuktikan alasan-alasan yang dibenarkan undang-undang untuk pengangkut tidak wajib bertanggung jawab atas hal tersebut (presumption of liability).

Berdasarkan syarat sahnya perjanjian yang diatur dalam KUHPerdata, akibat hukum atas cacatnya syarat causa atau sebab yang halal yaitu batal demi hukum, dalam arti klausula eksonerasi tersebut dianggap tidak mempunyai kekuatan hukum dan dianggap tidak pernah ada atau dicantumkan dalam dokumen angkutan udara perusahaan penerbangan Lion Air, dikarenakan terhadap klausula tersebut otomatis dibatalkan oleh hukum sebagaimana juga diatur dalam UUPK. Sehingga mengenai tanggung jawab atas keterlambatan pengangkutan udara berlaku ketentuan yang diatur dalam undang-undang di bidang angkutan udara.

Ketiga, mengenai pelaksanaan apa yang telah disepakati. Dalam suatu perjanjian, masing-masing pihak memiliki hak untuk menuntut pemenuhan prestasi sebagai konsekuensi atas apa yang telah mereka disepakati. Dalam pengangkutan udara pelaksanaan prestasi disini berupa kewajiban penumpang untuk membayar ongkos angkut dan kewajiban pengangkut yaitu mengantarkan penumpang ke tempat tujuan sesuai dengan yang diperjanjikan. Adanya keterlambatan pengangkutan menandakan telah terjadi penundaan prestasi pengangkut yang mana atas penundaan tersebut undang-undang membebankan pengangkut untuk bertanggung jawab. Akan tetapi dengan dicantumkannya klausula eksonerasi atas keterlambatan pengangkutan dalam tiket penumpang perusahaan penerbangan Lion Air, berarti ada itikad tidak baik dari pihak Lion Air untuk melakukan pemenuhan dan pelaksanaan perjanjian sesuai dengan yang telah disepakati dan menghilangkan tanggung jawabnya untuk mengganti kerugian atas penundaan prestasinya.

Berdasarkan ketiga indikator penguji asas keseimbangan diatas, dapat disimpulkan bahwa 
dicantumkannya klausula eksonerasi atas keterlambatan pengankutan dalam dokumen angkutan udara perusahaan penerbangan Lion Air diatas menandakan adanya suatu hubungan atau keadaan tidak seimbang mengenai pengaturan hak dan kewajiban para pihak dalam perjanjian pengangkutan udara khususnya mengenai tanggung jawab atas keterlambatan. Sehingga, klausula baku yang awalnya lahir demi menunjang efisiensi dan efektivitas dalam transaksi ini, pada akhirnya berbenturan dengan keseimbangan para pihak dalam perjanjian karena kedudukan antara pengangkut dengan penumpang menjadi tidak seimbang, dalam arti pencantuman klausula eksonerasi atas keterlambatan pengangkutan dalam tiket penumpang angkutan udara Lion Air bertentangan dengan asas keseimbangan dalam perjanjian.

\section{Penutup}

Pertama, klausula eksonerasi dalam dokumen angkutan udara pada perusahaan Lion Air merupakan klausula baku yang dilarang sebagaimana dimaksud dalam Pasal
18 UUPK dimana merupakan klausula yang menyatakan pengalihan tanggung jawab atas keterlambatan pengangkutan yang juga bertentangan dengan tanggung jawab atas keterlambatan yang diatur dalam peraturan perundangundangan di bidang angkutan udara, dikarenakan pada dasarnya pengangkut adalah wajib bertanggung jawab atas kerugian yang diderita penumpang yang dikarenakan keterlambatan pengangkutan sampai dapat membuktikan adanya faktor cuaca dan teknis operasional yang menyebabkan keterlambatan. Sehingga adanya klausula tersebut dinyakatakan batal demi hukum.

Kedua, klausula eksonerasi tentang keterlambatan pengangkutan pada perusahaan penerbangan Lion Air melanggar asas keseimbangan, karena pada dasarnya dalam perjanjian pengangkutan udara baik Lion Air maupun pengguna jasa angkutan udara memiliki kedudukan hukum yang sederajat atau sama tinggi. Adanya klausula eksonerasi menimbulkan ketidakseimbangan pengaturan hak dan kewajiban antara 
Lion Air dengan penumpang angkutan udara, yaitu telah menghapus hak konsumen untuk mendapatkan kompensasi dan ganti rugi atas kerugian yang diderita akibat keterlambatan pengangkutan sebagimana yang telah diatur undang-undang.

\section{Daftar Pustaka}

Ahmad Miru, Sutarman Yodo, 2005, Hukum Perlindungan

Konsumen, PT. Raja Grafindo, Jakarta.

European Observatory on Airport Capacity \& Quality, 2015, Delays to Air Transport in Europe : Methods of Measuring, Reporting and Analysing, Final Report of TASK FORCE.

H.M.N. Purwosutjipto, 1991, Pengertian Pokok Hukum Dagang, Hukum Pengangkutan Jilid 3, Djambatan, Jakarta.

Herlien Budiono, 2006, Asas Keseimbangan Bagi Hukum Perjanjian Indonesia : Hukum Perjanjian Berlandaskan Asas-
Asas Wigati Indonesia, PT.

Citra Aditya Bakti, Bandung.

Heru P. Sanusi, at. al., 2006, Diktat Hukum Dagang, Fakultas Hukum Universitas Trisakti, Jakarta.

Kitab Undang-Undang Hukum Perdata.

Mariam Darus Badrulzaman, 1994, Aneka Hukum Bisnis, Alumni, Bandung.

Mariam Darus Badrulzaman, at., al., 2001, Kompilasi Hukum Perikatan, PT. Citra Adytia Bakti, Bandung.

Mhd. Subhi Solih Hasibuan Tan Kamello, Hasim Purba, Rosnidar Sembiring, 2017, Tanggung Jawab Maskapai Penerbangan Atas Keamanan Penumpang Dalam Rute Penerbangan Non Izin Di Tinjau Dari Undang-Undang Republik Indonesia Nomor 1 Tahun 2009 Tentang Penerbangan, USU Law Journal, Vol. 5. No. 3.

Munir Fuady, 2008, Hukum Kontrak (Dari Sudut Pandang Hukum 
Bisnis), Buku 2, PT Citra

Aditya Bakti, Bandung.

Peraturan Menteri Perhubungan

Nomor 77 Tahun 2011 tentang

Tanggung Jawab Pengangkut.

Peraturan Menteri Perhubungan

Nomor 89 Tahun 2015 tentang

Penanganan Keterlambatan

Penerbangan (Delay

Management) Pada Badan

Usaha Angkutan Udara Niaga

Berjadwal Di Indonesia.

Siti Nurbaiti, 2007, Hukum Pengangkutan Darat (Jalan dan Kereta Api), Edisi 1, Pusat

Studi Hukum Transportasi dan

Telekomunikasi Universitas

Trisakti, Jakarta.

Soejono Dirdjosisworo, 2006,

Pengantar Hukum Dagang

Internasional, Refika Aditama,

Bandung.

Sri Redjeki Hartono, Husni Syawali,

Neni Sri Imaniyati, 2000,

Kapita Selekta Hukum

Ekonomi, Cetakan 1, CV.

Mandar Maju, Bandung.

Sri Sutarwati, Hardiyana, Novita

Karolina, 2016, Tanggung
Jawab Pengusaha Angkutan

Udara Terhadap Penumpang

Maskapai Garuda Indonesia Yang Mengalami

Keterlambatan Penerbangan

Di Bandar Udara

Internasional Adi Soemarno

Solo, Jurnal Ground Handling

Dirgantara Vol. 3, No. 2.

Sutan Remy Sjahdeini, 1993, Kebebasan Berkontrak dan Perlindungan Yang Seimbang Bagi Para Pihak dalam Perjanjian Kredit Bank di Indonesia, Institut Bankir Indonesia, Jakarta.

Toto Tohir Suriaatmadja, 2006, Masalah dan Aspek Hukum dalam Pengangkutan Nasional, Cetakan 1, CV. Mandar Maju, Bandung.

Toto Tohir Suriatmadja, 2005, Pengangkutan Kargo Udara: Tanggung Jawab Pengangkut Dalam Dimensi Hukum Udara Nasional \& Internasional, Pustaka Bani Quraisy, Bandung.

Undang-Undang Nomor 1 Tahun 2009 tentang Penerbangan. 
Angger Puja Andhika Adityawarman, Klausula Eksonerasi Dalam Dokumen Angkutan Udara...

Undang-Undang Nomor 8 Tahun

Konsumen.

1999 tentang Perlindungan 